\title{
2-Hydroxy-5-(3,5,7-trihydroxy-4-oxo-4H-chromen-2-yl)phenyl (E)-3-(4-hydroxy-3-methoxyphenyl)acrylate: Synthesis, In Silico Analysis and In Vitro Pharmacological Evaluation
}

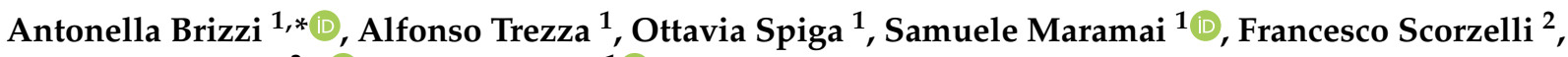 \\ Simona Saponara ${ }^{3, *}$ and Fabio Fusi ${ }^{1}$ (D) \\ 1 Department of Biotechnology, Chemistry and Pharmacy, DoE 2018-2022, University of Siena, Via A. Moro 2, \\ 53100 Siena, Italy; trezzaalfonso@gmail.com (A.T.); ottavia.spiga@unisi.it (O.S.); maramai@unisi.it (S.M.); \\ fabio.fusi@unisi.it (F.F.) \\ 2 Recipharm (Edmond Pharma), Strada Statale dei Giovi 131, Paderno Dugnano, 20037 Milano, Italy; \\ scorzelli.francesco@tiscali.it \\ 3 Department of Life Sciences, University of Siena, Via Aldo Moro 2, 53100 Siena, Italy \\ * Correspondence: antonella.brizzi@unisi.it (A.B.); simona.saponara@unisi.it (S.S.); Tel.: +39-0577-232409 (A.B.); \\ $+39-0577-232369$ (S.S.)
}

check for updates

Citation: Brizzi, A.; Trezza, A.; Spiga, O.; Maramai, S.; Scorzelli, F.; Saponara, S.; Fusi, F.

2-Hydroxy-5-(3,5,7-trihydroxy-4-oxo$4 H$-chromen-2-yl)phenyl

(E)-3-(4-hydroxy-3-

methoxyphenyl)acrylate: Synthesis, In Silico Analysis and In Vitro Pharmacological Evaluation. Molbank 2021, 2021, M1258. https://doi.org/ 10.3390/M1258

Academic Editors: Bernd Schneider and Bartolo Gabriele

Received: 18 May 2021

Accepted: 6 July 2021

Published: 23 July 2021

Publisher's Note: MDPI stays neutral with regard to jurisdictional claims in published maps and institutional affiliations.

Copyright: (c) 2021 by the authors. Licensee MDPI, Basel, Switzerland. This article is an open access article distributed under the terms and conditions of the Creative Commons Attribution (CC BY) license (https:/ / creativecommons.org/licenses/by/ $4.0 /)$.
Abstract: Quercetin and ferulic acid are two phytochemicals extensively represented in the plant kingdom and daily consumed in considerable amounts through diets. Due to a common phenolic structure, these two molecules share several pharmacological properties, e.g., antioxidant and free radical scavenging, anti-cancer, anti-inflammatory, anti-arrhythmic, and vasorelaxant. The aim of the present work was the combination of the two molecules in a single chemical entity, conceivably endowed with more efficacious vasorelaxant activity. Preliminary in silico studies herein described suggested that the new hybrid compound bound spontaneously and with high affinity on the $\mathrm{K}_{\mathrm{Ca}} 1.1$ channel. Thus, the synthesis of the $3^{\prime}$-ferulic ester derivative of quercetin was achieved and its structure confirmed by ${ }^{1} \mathrm{H}$ - and ${ }^{13} \mathrm{C}-\mathrm{NMR}$ spectra, $\mathrm{HSQC}$ and $\mathrm{HMBC}$ experiments, mass spectrometry, and elementary analysis. The effect of the new hybrid compound on vascular $\mathrm{K}_{\mathrm{Ca}} 1.1$ and $\mathrm{Ca}_{\mathrm{V}} 1.2$ channels revealed a partial loss of the stimulatory activity that characterizes the parent compound quercetin. Therefore, further studies are necessary to identify a better strategy to improve the vascular properties of this flavonoid.

Keywords: ferulic acid; quercetin; ester-based derivatives; $\mathrm{K}_{\mathrm{Ca}} 1.1$ channel; $\mathrm{Ca}_{\mathrm{V}} 1.2$ channel; patchclamp; docking simulation; homology modeling

\section{Introduction}

Plant-derived secondary metabolites are non-nutrient compounds that aroused research interest due to their heterogeneous chemical structures complementary to a myriad of pharmacological activities. In this scenario, quercetin, one of the most studied and wellknown phytochemicals, is the flavonol that exhibits many interesting healthy properties, particularly on the cardiovascular system [1]. A growing body of evidence indicates that these beneficial effects are driven by a direct modulation of ion channel function and/or channel protein expression, trafficking, and signaling [2-5]. In particular, the modulatory effects of quercetin on $\mathrm{Ca}_{\mathrm{V}} 1.2$ and $\mathrm{K}_{\mathrm{Ca}} 1.1$ channels, playing a fundamental role in the regulation of vascular smooth muscle tone, have been comprehensively described [6,7]. In this context, drugs endowed with vascular bifunctional activity (namely, stimulation of $\mathrm{K}_{\mathrm{Ca}} 1.1$ and inhibition of $\mathrm{Ca}_{\mathrm{V}} 1.2$ channels) are of potential interest for the treatment of systemic hypertension. In fact, high blood pressure triggers an arterial "ion channel remodeling", a phenomenon involving the upregulation of Cav1.2 channels [8] coupled to the down-regulation of voltage-dependent $\mathrm{K}^{+}\left(\mathrm{K}_{\mathrm{V}}\right)$ channels. Consequently, a compensatory overexpression of $\mathrm{K}_{\mathrm{Ca}} 1.1$ channels occurs, which helps avert local vasospasm [9]. Therefore, 
designing vasodilator drugs, which target and counterbalance disease-specific changes of ion channel expression, would seem a logical approach for developing antihypertensive agents. Noticeably, a close relationship between chemical modifications and activity within quercetin family is reported and exploited both to generate functional diversity and to overcome stability and bioavailability limits [10]. In the search for novel flavonoid derivatives [11-14], the acylation approach came out as an effective tool for obtaining hybrid compounds selectively decorated with a natural acid residue in the polyhydroxylated 2-phenyl-4H-chromen-4-one core. Accordingly, ferulic acid, a cinnamic-derived plant metabolite abundant in foods, is considered a protective agent with a very versatile and safe pharmacological profile [15]. Its endothelial protective effects [16] prompted us to hypothesize that combination of this molecule with quercetin in a single chemical entity might give rise to a potent vasoactive compound with better physico-chemical properties. Indeed, the synthesis of 3 -ferulic ester derivative of quercetin, i.e., 2-hydroxy-5-(3,5,7trihydroxy-4-oxo-4H-chromen-2-yl)phenyl (E)-3-(4-hydroxy-3-methoxyphenyl)acrylate 1, is here reported together with the assessment of its vascular ion channel modulatory activity both in silico and in vitro.

The effects of compound 1 on $\mathrm{Ba}^{2+}$ current through Cav 1.2 channels $\left(\mathrm{I}_{\mathrm{Ba} 1.2}\right)$ and on $\mathrm{K}^{+}$ current through $\mathrm{K}_{\mathrm{Ca}} 1.1$ channels $\left(\mathrm{I}_{\mathrm{KCa}} \mathrm{a} .1\right)$, which play a fundamental role in the regulation of vascular smooth muscle tone, were investigated in rat tail artery myocytes using the whole-cell patch-clamp method.

\section{Results and Discussion}

\subsection{In Silico Analysis}

An in silico docking approach was followed to evaluate the potential activity of both mono-ferulic ester derivatives of quercetin, compound 1, i.e., $3^{\prime}$-O-feruloyl derivative, and compound 2, i.e., the $4^{\prime}-\mathrm{O}$-feruloyl derivative, on $\mathrm{K}_{\mathrm{Ca}} 1.1$ channels. A rational docking simulation was carried out within the $\mathrm{K}_{\mathrm{Ca}} 1.1$ channel binding site proposed by Carullo and colleagues [12]. The docking result showed that both compounds bound spontaneously to the target, exhibiting a not significantly different binding free energy $(-8.7 \mathrm{kcal} / \mathrm{mol}$ for compound 1 and $-9.1 \mathrm{kcal} / \mathrm{mol}$ for compound 2) and a docking pose very similar within the binding pocket (Figure 1B). The interaction network analysis was evaluated by the protein-ligand interaction profile (PLIP) tool. Compound $\mathbf{1}$ was able to bind in a sensing region of the $\mathrm{K}_{\mathrm{Ca}} 1.1$ channel, triggering several interactions with the target key residues [12,17] (Figure 1C and Table S1). Analogously, compound 2 triggered different interactions inside the target binding site (Figure 1D), forming an interaction network with residues identified as crucial for $\mathrm{K}_{\mathrm{Ca}} 1.1$ channel activity $[12,17]$ (Table S1). The high binding affinity and the wide interaction network of compounds $\mathbf{1}$ and $\mathbf{2}$ in a sensing region of the $\mathrm{K}_{\mathrm{Ca}} 1.1$ channel located in the S6/RCK linker [18], would support the hypothesis of a potential modulating activity of our derivatives against $\mathrm{K}_{\mathrm{Ca}} 1.1$ channel. 

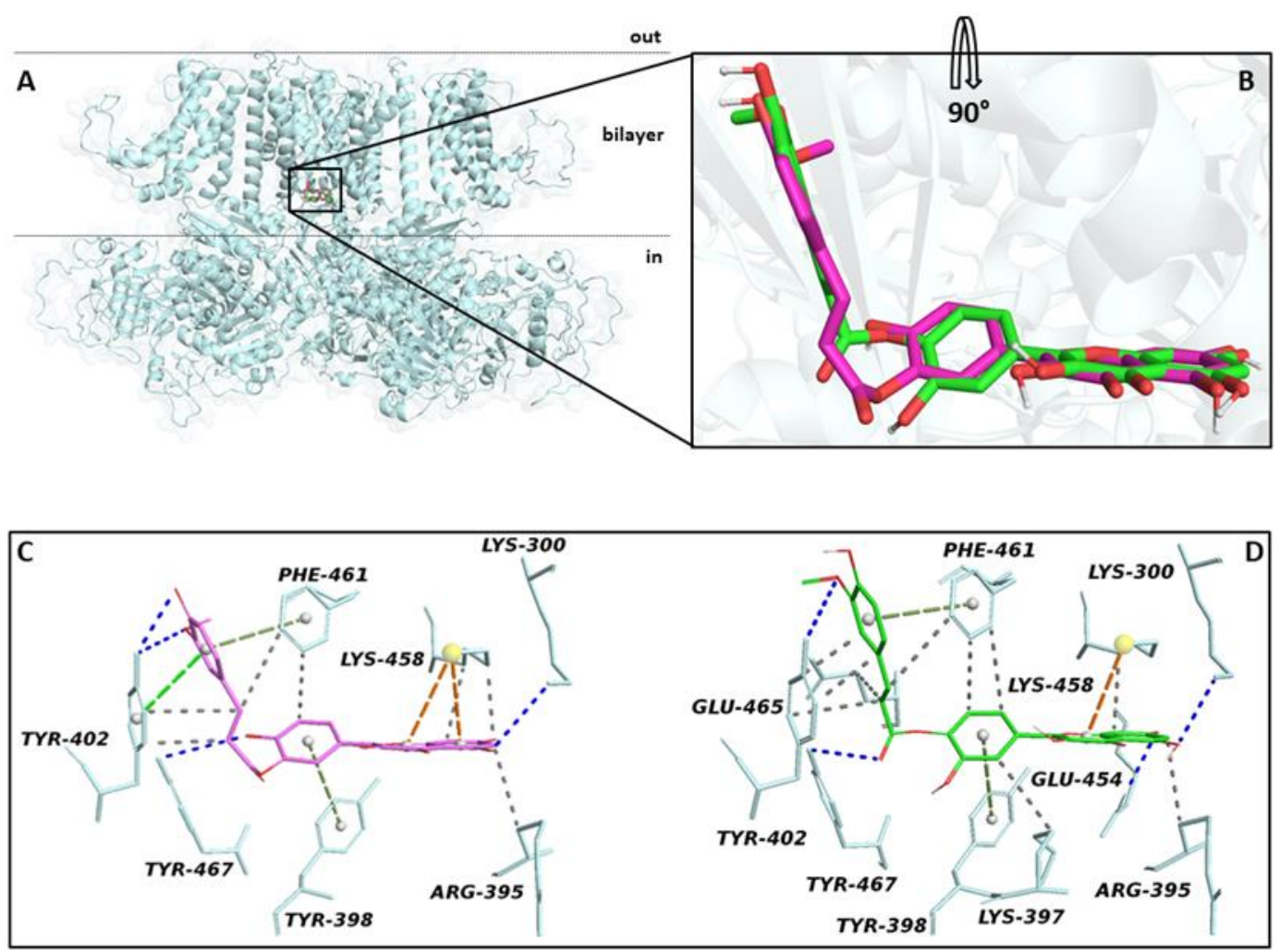

Figure 1. $\mathrm{K}_{\mathrm{Ca}} 1.1$ channel/compounds 1 and 2 docked pose overview. (A) The $\mathrm{K}_{\mathrm{Ca}} 1.1$ channel is shown as a transparent cyan surface-cartoon while the binding pocket is shown in cyan surface. The ligands are reported in green sticks and balls. The membrane bilayer is delimited by two black dotted lines. (B) Zoom in of the compounds within $\mathrm{K}_{\mathrm{Ca}} 1.1$ channel binding pocket. (C,D) $\mathrm{K}_{\mathrm{Ca}} 1.1$ channel/compounds $\mathbf{1}$ and $\mathbf{2}$ interaction network. The binding residues are colored in cyan sticks and balls. Hydrogen bonds, hydrophobic interactions, $\pi$-stacking and $\pi$-cationic interactions are represented as blue, grey, green and orange dotted lines, respectively.

\subsection{Chemistry}

Regioselective synthesis of mono-O-substituted quercetin analogues is a challenging task as the results reported in the literature demonstrate [19-21]. In fact, quercetin hydroxyls are not equivalent in terms of chemical reactivity and slight modifications in reaction conditions, such as temperature, timing, order of the reagent addition, and nature of the acylating/alkylating agent, can lead to different mono-O-derivatives or complex reaction mixtures. Therefore, the enzymatic approach is often preferred to obtain selective acylation of the phenolic compound [22-24] and, specifically, Kumar and collaborators reported the regioselective synthesis of quercetin ferulate using Rhizopus oryzae lipase [25]. Nevertheless, in a previous work [12] a simple and mild one-step procedure to obtain the $4^{\prime}$-regioselective acylation of quercetin was used, by reacting controlled amounts of the appropriate acids and the natural flavonol in the presence of a water-soluble carbodiimide as carboxyl activating agent. The direct acylation procedure of quercetin under strictly controlled conditions was also successfully reported by Veverka and collaborators [21] as a time-saving alternative. Thus, by modifying our previous procedure to partially overcome the solubility issues of the starting flavonol, the $3^{\prime}$-ferulic ester derivative of quercetin was selectively obtained in acceptable yield (28.0\%). In fact, compound 1 was obtained by reacting quercetin (Que) dihydrate with ferulic acid (stoichiometric ratio of 1:1) in the presence of $N$-ethyl- $N^{\prime}$-(3-dimethylaminopropyl)carbodiimide (EDCI) and 1-hydroxybenzotriazole $(\mathrm{HOBt})$ in dry dichloromethane $/ \mathrm{N}, \mathrm{N}$-dimethylformamide (DCM/DMF, procedure A) or acetonitrile (procedure B, Scheme 1) at room temperature. Although the addition of DMF to DCM resulted in a clear yellow solution, acetonitrile alone is an excellent alternative when the reagents are poorly soluble in dichloromethane and allowed to eliminate part 
of the unreacted quercetin from the reaction mixture by simple filtration of the partially concentrated suspension. The purification of the raw reaction material represented the limiting step to obtaining the desired product in high yield. However, the C- $3^{\prime}$ ferulic ester of quercetin was the only coupling product isolated as demonstrated by NMR experiments $\left({ }^{1} \mathrm{H},{ }^{13} \mathrm{C}, \mathrm{HSQC}\right.$ and $\left.\mathrm{HMBC}\right)$, mass spectra and elemental analysis (see Supplementary Material). No other mono-O-substituted ester regioisomers were isolated and identified while traces of a diacylated product of quercetin $\left.(653 \mathrm{M}-\mathrm{H}]^{-}\right)$and the homocoupling product of ferulic acid $\left.(369 \mathrm{M}-\mathrm{H}]^{-}\right)$were detected. The unreacted ferulic acid was mainly recovered as a coupling product with hydroxybenzotriazole $\left(310[\mathrm{M}-\mathrm{H}]^{-}\right)$. Concerning the correctness of the proposed structure of compound 1, the five quercetin hydroxyls are known to have a different reactivity and steric hindrance. Specifically, 3-OH and 5-OH hydroxyl groups are the least reactive being involved in an intramolecular hydrogen bond with the oxygen of the carbonyl in position 4 [26]; among the other three hydroxyl groups, the reactivity order strongly depends on the reaction conditions used, even if the results reported in the literature are non-homogeneous and often inconsistent $[21,23,27,28]$. The mild reaction conditions (a water-soluble carbodiimide as coupling agent, a molar equivalent of the acid, high dilution, and room temperature) promoted the acylation in position $3^{\prime}$. The whole assignment of the NMR signals was confirmed by HSQC and HMBC analyses while the site of acylation was confirmed by comparing upfield and/or downfield shifts in NMR spectra between ester derivative $\mathbf{1}$ and quercetin signals (see Table 1).<smiles>O=c1c(O)c(-c2ccc(O)c(O)c2)oc2cc(O)cc(O)c12</smiles>
quercetin<smiles>COc1cc(/C=C/C(=O)O)ccc1O</smiles>

ferulic acid

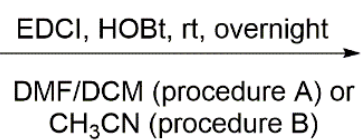

$\mathrm{CH}_{3} \mathrm{CN}$ (procedure $\mathrm{B}$ )

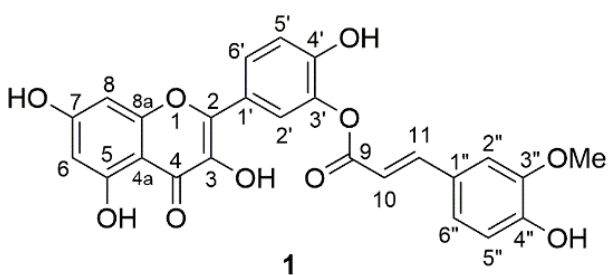

1

Scheme 1. Synthesis of $3^{\prime}$-ferulic ester derivative of quercetin.

Table 1. ${ }^{1} \mathrm{H}$ - and ${ }^{13} \mathrm{C}-\mathrm{NMR}\left(600 \mathrm{MHz}\right.$, DMSO- $d_{6}$ ) chemical shifts of the protons and carbons of quercetin (Que) and $3^{\prime}$-ferulic quercetin ester (Compd. 1).

\begin{tabular}{|c|c|c|}
\hline $\begin{array}{c}\text { Hydrogen/Carbon } \\
\text { Position }\end{array}$ & $\underset{\delta}{\text { Que }}$ & $\underset{\delta}{\text { Compd. } 1}$ \\
\hline $\mathrm{C}$ in $3^{1}$ & 136.2 & 136.6 \\
\hline$C$ in 5 & 161.2 & 161.2 \\
\hline $\mathrm{C}-\mathrm{H}$ in 6 & $6.18 / 98.7$ & $6.19 / 98.7$ \\
\hline $\mathrm{C}$ in 7 & 164.3 & 164.5 \\
\hline $\mathrm{C}-\mathrm{H}$ in 8 & $6.40 / 93.8$ & $6.46 / 94.1$ \\
\hline $\mathrm{C}-\mathrm{H}$ in $2^{\prime}$ & $7.67 / 115.5$ & $7.92 / 123.3$ \\
\hline $\mathrm{C}$ in $3^{\prime}$ & 145.5 & 138.8 \\
\hline $\mathrm{C}$ in $4^{\prime}$ & 148.2 & 151.6 \\
\hline $\mathrm{C}-\mathrm{H}$ in $5^{\prime}$ & $6.88 / 116.1$ & $7.11 / 117.3$ \\
\hline $\mathrm{C}-\mathrm{H}$ in $6^{\prime}$ & $7.53 / 120.4$ & $7.96 / 126.8$ \\
\hline
\end{tabular}

${ }^{1}$ Number position refers to that of Scheme 1.

Specifically, in the 2-phenyl-4H-chromen-4-one system the chemical shift values of carbons 3,5 , and 7 as well as those of the protons in 6 and 8 are unchanged (Table 1), excluding the hydroxyls in 7, 5, and 3 as acylation sites. Acylation at $3^{\prime}$ position was supported by the significant upfield shift of the $3^{\prime}$ carbon value (138.8 ppm of compd. 1 vs. $145.5 \mathrm{ppm}$ of Que) associated with the significant downfield shift of the $4^{\prime}$ carbon value (151.6 ppm of compd. 1 vs. 148.2 ppm of Que, Table 1). Moreover, the presence of the ferulic portion moved the carbon and proton chemical shifts of all neighboring protons/carbons $\left(2^{\prime}, 5^{\prime}\right.$ and $\left.6^{\prime}\right)$ to lower field and among these both the $2^{\prime}-$ and $6^{\prime}-\mathrm{CH}$ values were the most affected (Table 1). According to data reported in the literature [21,29], the assignment of 
signals is consistent with the proposed structure. The mass spectrum of compound $\mathbf{1}$ also provided the expected $[\mathrm{M}-\mathrm{H}]^{-}$peak $(100 \%$ intensity) for the assigned structure, also confirmed by the elementary analysis.

\subsection{Pharmacological Evaluation}

\subsubsection{Effect of Compound 1 on $\mathrm{I}_{\mathrm{KCa} 1.1}$}

This series of experiments was carried out to evaluate whether the presence of ferulic acid in $3^{\prime}$ position might affect quercetin stimulation of $\mathrm{K}_{\mathrm{Ca}} 1.1$ channel. Under the conditions used in the present experiments, the outward current mostly consisted of iberiotoxin-sensitive $\mathrm{I}_{\mathrm{KCa} 1.1}$ current. Figure $2 \mathrm{~A}$ shows the current-voltage relationships of $\mathrm{I}_{\mathrm{KCa} .1}$ elicited with clamp pulses in the range $-20 \mathrm{mV}$ and $70 \mathrm{mV}$ from a $\mathrm{V}_{\mathrm{h}}$ of $-40 \mathrm{mV}$, under control conditions and after the cumulative addition of 30-100 $\mu \mathrm{M}$ compound 1 . The derivative stimulated current amplitude in a concentration-dependent manner and in particular, at $70 \mathrm{mV}, 100 \mu \mathrm{M}$ compound 1 increased $\mathrm{I}_{\mathrm{KCa} 1.1}$ by $115 \%$, less than that observed with quercetin $(210 \%)$ under similar experimental conditions [7]. Figure 2B shows the time course of current amplitude stimulation induced by compound 1 that, at the maximal concentration assessed, did not significantly modify the time course of activation of the current evoked by the depolarizing pulses to $70 \mathrm{mV}$ (Figure 2B inset). Under control conditions, in fact, $\tau$ of activation was $45.3 \pm 5.8 \mathrm{~ms}(n=5)$ and a similar value was recorded in the presence of $100 \mu \mathrm{M}$ compound $1(38.5 \pm 6.9)$. Similar results were observed with quercetin [7]. Taken together, these data demonstrated that the $3^{\prime}$-ferulic acid ester derivative halves the stimulatory efficacy of the flavonoid towards $\mathrm{I}_{\mathrm{KCa} 1.1}$.
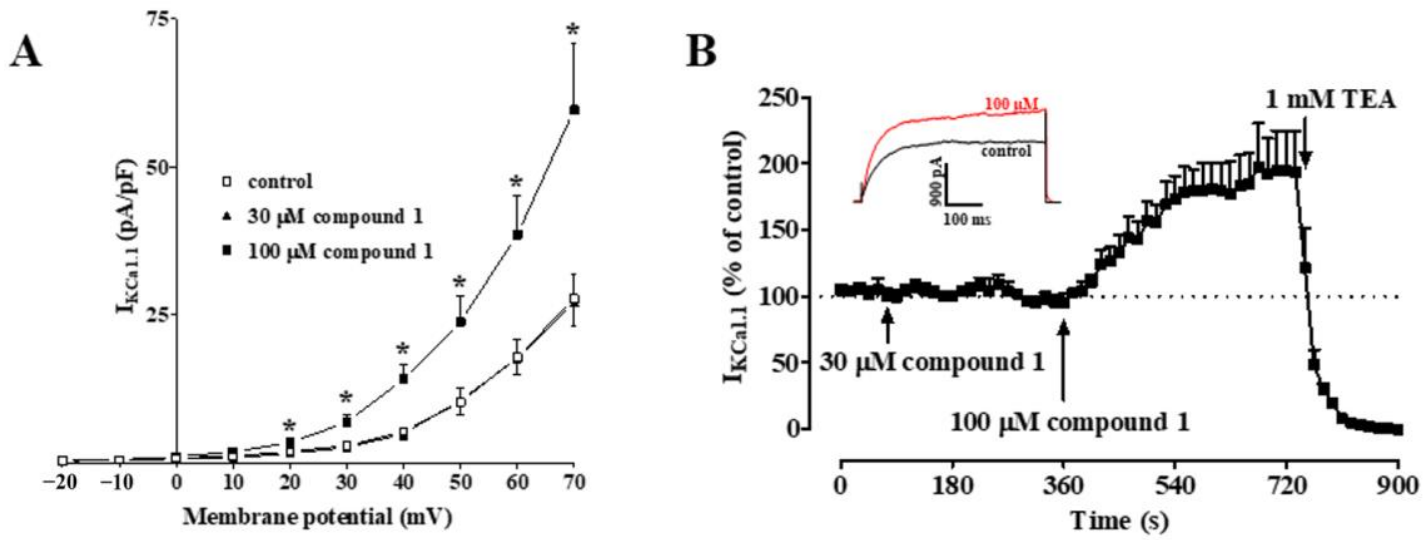

Figure 2. Effects of compound 1 on $\mathrm{I}_{\mathrm{KCa} 1.1}$ recorded in rat tail artery myocytes. (A) Concentration-dependent effect of compound 1. On the ordinate scale $\mathrm{I}_{\mathrm{KCa} 1.1}$ amplitude is reported in $\mathrm{pA} / \mathrm{pF}$. Data points are means \pm s.e.m. $(n=5) .{ }^{*} p<0.05$, repeated measures ANOVA and Dunnett's post-test vs. control. (B) Time-course of current stimulation caused by compound 1. On the ordinate scale $\mathrm{I}_{\mathrm{KCa} 1.1}$ is reported as percentage of that recorded just before the addition of the first concentration of the derivative. The effect of $1 \mathrm{mM}$ TEA, which blocked $\mathrm{I}_{\mathrm{KCa} 1.1}$, is also shown. Inset: current traces (averaged from 5 cells) recorded in the absence (control) or presence of compound 1. $\mathrm{I}_{\mathrm{KCa}} .1$ was elicited with a clamp pulse to $70 \mathrm{mV}$ from a $\mathrm{V}_{\mathrm{h}}$ of $-40 \mathrm{mV}$, delivered every $10 \mathrm{~s}$.

\subsubsection{Effect of Compound 1 on $I_{\text {Ba1.2 }}$}

This series of experiments was carried out to evaluate the effect of compound 1 on vascular $\mathrm{I}_{\mathrm{Ba1} \text {.2. }}$. Figure $3 \mathrm{~A}$ shows recordings of the inward current elicited with a clamp pulse to $0 \mathrm{mV}$ from a $\mathrm{V}_{\mathrm{h}}$ of $-50 \mathrm{mV}$ under control conditions and after the addition of cumulative concentrations of the hybrid derivative. Compound 1 showed a biphasic behavior, first stimulating (maximal effect of $141 \%$ at $30 \mu \mathrm{M}$ concentration) and then bringing current amplitude back to control values (Figure 3B). Under similar experimental conditions quercetin stimulated $\mathrm{I}_{\mathrm{Ba} 1.2}$ with an $\mathrm{EC}_{50}$ value of $8.1 \mu \mathrm{M}$ and a maximal effect of $227 \%$ at $50 \mu \mathrm{M}$ concentration [6]. These findings demonstrate that quercetin derivatization with a ferulic acid moiety attached to the $3^{\prime}$ position, as occurred in compound 1 , gave rise to a novel 
agent endowed of a weaker $\mathrm{Ca}_{\mathrm{V}} 1.2$ channel stimulating activity as compared to the parent flavonoid. $\mathrm{I}_{\mathrm{Ba} 1.2}$ evoked at $0 \mathrm{mV}$ from a $\mathrm{V}_{\mathrm{h}}$ of $-50 \mathrm{mV}$ activated and then declined with a time course that could be fitted by a monoexponential function. Compound 1 significantly slowed the $\tau$ of activation, showing a bell-shaped pattern (Figure 3C,D). This behavior almost overlapped that observed on current amplitude. The marked delay in channel activation caused by compound $\mathbf{1}$ affected $\tau$ of inactivation measurement, at least in the concentration range 3-30 $\mu \mathrm{M}$. Under similar experimental conditions quercetin also slowed down significantly the $\tau$ of activation without affecting that of inactivation [6]. Taken together, these findings demonstrate that the derivatization here pursued did not modify the capability of the parent compound to slow down the transition of $\mathrm{Ca}_{\mathrm{V}} 1.2$ channels from the closed to the open state or, in some other way, to modify the gating mechanism.

A

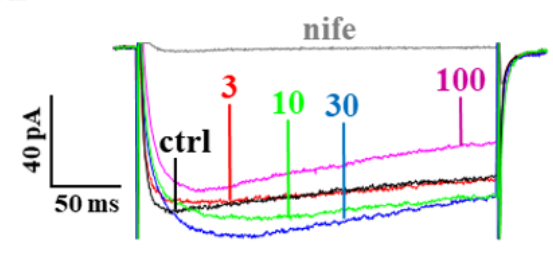

C

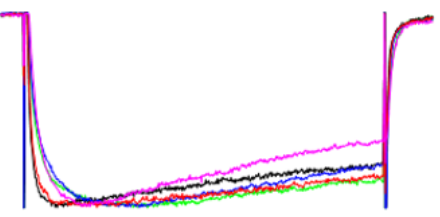

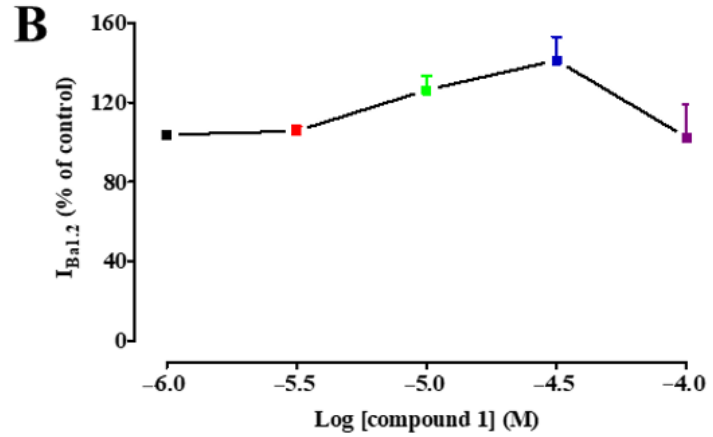

D

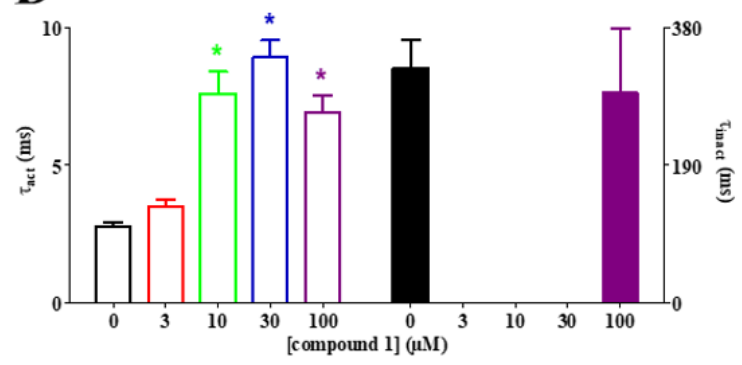

Figure 3. Effect of compound 1 on $\mathrm{I}_{\mathrm{Ba} 1.2}$ amplitude and kinetics recorded in rat tail artery myocytes. (A) Current traces (averaged from 5 cells) recorded with a clamp pulse to $0 \mathrm{mV}$ from a $\mathrm{V}_{\mathrm{h}}$ of $-50 \mathrm{mV}$ in the absence (ctrl) or presence of various concentrations $(\mu \mathrm{M})$ of compound 1. (B) Concentration-dependent effect of compound 1. On the ordinate scale $\mathrm{I}_{\mathrm{Ba} 1.2}$ amplitude is reported as percentage of that recorded just before drug addition. Data points are means \pm s.e.m. $(n=4-6)$. (C) Current traces (shown in panel A) sized so that the peak amplitude of the traces in presence of the drug matched that of control. (D) Concentration-dependent effect of compound 1 on time constants of either current activation ( $\tau_{\text {act; }}$ open columns) or current inactivation ( $\tau_{\text {inact }}$; closed columns). Columns are means \pm s.e.m. $(n=5) * p<0.05$, repeated measures ANOVA and Dunnett's post-test vs. control.

\section{Materials and Methods}

\subsection{In Silico Methods}

The homology 3D model of the Rattus norvegicus $\mathrm{K}_{\mathrm{Ca}} 1.1$ channel was obtained as reported in a previous work [5]. The 3D structure of compound $\mathbf{1}$ was drawn using Chemdraw software and then optimized using the Dock Prep [30]. To examine the potential binding pose of the compound on the target, a flexible docking simulation was performed with AutoDock/VinaXB [31]. The pdbqt file of the ligand was obtained by Open Babel tool v. 2.4.1 [32], while pdbqt format of the receptor was generated by using the Molecular Graphics Laboratory software (MGLTools) [33]. Multiple ligand-protein interaction maps were generated using the Protein-Ligand Interaction Profiler (PLIP) [34]. PyMOL v. 2.2 
was used as molecular graphic system (The PyMOL Molecular Graphics System, Version 2.2, Schrödinger, LLC, New York, NY, USA).

\subsection{Chemistry}

\subsubsection{General}

Reagents and solvent were purchased from Merck (Milan, Italy) and used without further purification. Anhydrous conditions were obtained by a positive pressure flow of dry nitrogen into oven-dried glassware and dried solvents were bought (dry DMF) or freshly prepared (dry DCM) using the proper drying agents. Organic solutions were dried over anhydrous sodium sulfate and concentrated using a rotary evaporator (Büchi R-110, Büchi, Milan, Italy) equipped with a KNF N 820 FT 18 vacuum pump. The final compound was purified by column chromatography (Merck 60 silica gel, 230-400 mesh, Milan, Italy) and checked for purity by thin layer chromatography (TLC plates, Merck 60 F254 aluminum silica plates, Milan, Italy). Melting points were measured with a Kofler hot stage apparatus (K) and are uncorrected. Its identity was unambiguously verified by nuclear magnetic resonance and mass spectroscopy. ${ }^{1} \mathrm{H}-\mathrm{NMR}$ and ${ }^{13} \mathrm{C}-\mathrm{NMR}$ spectra as well as 2D-NMR experiments (HSQC and HMBC) were recorded on a Bruker Advance (Milan, Italy) operating at $600 \mathrm{MHz}$ in the indicated solvent at $25^{\circ} \mathrm{C}$, and chemical shifts were expressed as $\delta(\mathrm{ppm})$ and the coupling constants $(J)$ in $\mathrm{Hz}$. Mass spectra were acquired in positive mode (mass range $m / z$ of 150-1500) using a chromatography-mass spectrometry (LC-MS) apparatus (Agilent 1100, supplied with a binary high-pressure gradient pump (flow rate of $0.4 \mathrm{~mL} / \mathrm{min}$, solvent system of $95 / 5$ methanol/water), a solvent degassing unit, and a UV detection (254 nm). Nitrogen (purity 99.995\%) was used as nebulizer and drying gas. Elemental analyses were performed on a Perkin-Elmer PE 2004 elemental system (Perkin Elmer, Milan, Italy) and the data for $\mathrm{C}, \mathrm{H}$, and $\mathrm{N}$ are within $0.4 \%$ of the theoretical values.

\subsubsection{Synthesis of 2-Hydroxy-5-(3,5,7-trihydroxy-4-oxo-4H-chromen-2-yl)phenyl}

(E)-3-(4-hydroxy-3-methoxyphenyl)acrylate (1)

Procedure A. In a round-bottomed flask equipped with a calcium chloride drying tube, to a stirred solution of quercetin dihydrate $(100.0 \mathrm{mg}, 0.32 \mathrm{mmol})$ in dry DMF/DCM mixture $(1 / 2,12 \mathrm{~mL})$ were added in the order ferulic acid $(62.0 \mathrm{mg}, 0.32 \mathrm{mmol})$ and $\mathrm{HOBt}$ (52.0 mg, $0.38 \mathrm{mmol}, 1.2$ equiv.); then, a solution of EDCI ( $82.4 \mathrm{mg}, 0.43 \mathrm{mmol}, 1.5$ equiv.) in dry DMC $(10 \mathrm{~mL})$ was added dropwise and the reaction was left to stand overnight. The DCM was removed and the mixture taken up with ethyl acetate $(40 \mathrm{~mL})$; the organic layer was washed twice with a $\mathrm{NH}_{4} \mathrm{Cl}$ saturated solution and, finally, once with brine. The collected organic layers, dried on anhydrous $\mathrm{Na}_{2} \mathrm{SO}_{4}$, were filtered and concentrated to dryness. Purification of the raw material by silica gel column chromatography, using a gradient elution (dichloromethane/methanol 50/4,50/5, 50/6), furnished compound 1 as a yellow solid. Yield: $25.0 \%$.

Procedure B. In a round-bottomed flask equipped with a calcium chloride drying tube, to a stirred suspension of quercetin dihydrate $(100.0 \mathrm{mg}, 0.32 \mathrm{mmol})$ in dry acetonitrile $(40 \mathrm{~mL})$ were added in the order ferulic acid $(62.0 \mathrm{mg}, 0.32 \mathrm{mmol})$ and HOBt $(52.0 \mathrm{mg}$, $0.38 \mathrm{mmol}, 1.2$ equiv.); then, a solution of EDCI ( $82.4 \mathrm{mg}, 0.43 \mathrm{mmol}, 1.5$ equiv.) in dry acetonitrile $(5 \mathrm{~mL})$ was added dropwise and the reaction was left to stand overnight. Afterwards, the reaction mixture was partially concentrated, filtered and then, concentrated to dryness. Purification of the raw material by silica gel column chromatography, using a gradient elution (dichloromethane/methanol 50/4, 50/5, 50/6), furnished compound 1 as a yellow solid. Yield: $28.0 \%$.

Yellow solid, mp 187-191 ${ }^{\circ} \mathrm{C}(\mathrm{K}) .{ }^{1} \mathrm{H}-\mathrm{NMR}$ (DMSO-d 6 ): $\delta 12.42$ (s, $1 \mathrm{H}, \mathrm{OH}$ in 5), 10.50 (br s, 2H, OH), $9.68(\mathrm{br} \mathrm{s}, 2 \mathrm{H}, \mathrm{OH}), 7.96\left(\mathrm{~d}, J=8.2 \mathrm{~Hz}, 1 \mathrm{H}, \mathrm{H}\right.$ in $\left.6^{\prime}\right), 7.92\left(\mathrm{~s}, 1 \mathrm{H}, \mathrm{H}\right.$ in $\left.2^{\prime}\right), 7.75$ $(\mathrm{d}, J=15.7 \mathrm{~Hz}, 1 \mathrm{H},-\mathrm{CH}=\mathrm{CH}-\mathrm{Ar}), 7.42\left(\mathrm{~s}, 1 \mathrm{H}, \mathrm{H}\right.$ in $\left.2^{\prime \prime}\right), 7.21\left(\mathrm{~d}, 1 \mathrm{H}, J=7.6 \mathrm{~Hz}, \mathrm{H}\right.$ in $\left.6^{\prime \prime}\right)$, $7.11\left(\mathrm{~d}, 1 \mathrm{H}, J=8.3 \mathrm{~Hz}, \mathrm{H}\right.$ in $\left.5^{\prime}\right), 6.83\left(\mathrm{~d}, 1 \mathrm{H}, J=7.6 \mathrm{~Hz}, \mathrm{H}\right.$ in $\left.5^{\prime \prime}\right), 6.73(\mathrm{~d}, J=15.9 \mathrm{~Hz}, 1 \mathrm{H}$, $\mathrm{CO}-\mathrm{CH}=\mathrm{CH}-\mathrm{Ar}), 6.46(\mathrm{~s}, 1 \mathrm{H}, \mathrm{H}$ in 8$), 6.19(\mathrm{~s}, 1 \mathrm{H}, \mathrm{H}$ in 6$), 3.84\left(\mathrm{~s}, 3 \mathrm{H}, \mathrm{OCH}_{3}\right) .{ }^{13} \mathrm{C}-\mathrm{NMR}$ 
$\left(\mathrm{DMSO}-d_{6}\right): \delta 176.4(\mathrm{C}=\mathrm{O}$ in 4$), 165.3(\mathrm{COO}), 164.5$ (Cq in 7), $161.2(\mathrm{Cq}$ in 5), 156.7 (Cq in $8 \mathrm{a}), 151.6\left(\mathrm{Cq}\right.$ in $\left.4^{\prime}\right), 150.2\left(\mathrm{Cq}\right.$ in $\left.3^{\prime \prime}\right), 148.5\left(\mathrm{Cq}\right.$ in $\left.4^{\prime \prime}\right), 147.4(\mathrm{CH}=\mathrm{CH}-\mathrm{Ar}), 146.1$ (Cq in 2), $138.8\left(\mathrm{Cq}\right.$ in $\left.3^{\prime}\right), 136.6$ (Cq in 3), $126.8\left(\mathrm{CH}\right.$ in $\left.6^{\prime}\right), 126.0$ (Cq in $\left.1^{\prime \prime}\right), 124.0\left(\mathrm{CH}\right.$ in $\left.6^{\prime \prime}\right), 123.3$ $\left(\mathrm{CH}\right.$ in $\left.2^{\prime}\right), 122.5\left(\mathrm{Cq}\right.$ in $\left.1^{\prime}\right), 117.3\left(\mathrm{CH}\right.$ in $\left.5^{\prime}\right), 116.1\left(\mathrm{CH}\right.$ in $\left.5^{\prime \prime}\right), 113.9(\mathrm{CO}-\mathrm{CH}=\mathrm{CH}-\mathrm{Ar}), 112.0$ (CH in 2"), 103.6 (Cq in 4a), 98.7 (CH in 6), $94.1\left(\mathrm{CH}\right.$ in 8), $56.2\left(\mathrm{OCH}_{3}\right)$. ESI-MS m/z: 477 [M $-\mathrm{H}]^{-}$(100). Elemental analysis for $\mathrm{C}_{25} \mathrm{H}_{18} \mathrm{O}_{10}$ found $\mathrm{C}, 62.55 ; \mathrm{H}, 3.80$; calculated C, 62.77; $\mathrm{H}, 3.79$.

\subsection{Pharmacological Analysis \\ 3.3.1. Animals}

All experimental protocols were approved by the Animal Care and Ethics Committee of the University of Siena and Italian Department of Health (7DF-19.N.TBT) and carried out in accordance with the European Union Guidelines for the Care and the Use of Laboratory Animals (European Union Directive 2010/63/EU). Male Wistar rats, weighing 325-450 g were purchased from Charles River Italia (Calco, Italy) and maintained in an animal house facility at $25 \pm 1{ }^{\circ} \mathrm{C}$ and 12:12 h dark-light cycle with free access to standard chow diet and water. Animals were anaesthetized with an isoflurane $(4 \%)$ and $\mathrm{O}_{2}$ gas mixture by using Fluovac (Harvard Apparatus, Holliston, MA, USA), decapitated and exsanguinated. The tail (cleaned of skin) was immediately removed and placed in external solution (see below for composition).

\subsubsection{Cell Isolation Procedure}

The tail main artery was dissected free of its connective tissue and smooth muscle cells were freshly isolated under the following conditions. A 5-mm long piece of artery was incubated at $37^{\circ} \mathrm{C}$ for $40-45 \mathrm{~min}$ in $2 \mathrm{~mL}$ of $0.1 \mathrm{mM} \mathrm{Ca}^{2+}$ external solution (in mM: 130 $\mathrm{NaCl}, 5.6 \mathrm{KCl}, 10 \mathrm{HEPES}, 20$ glucose, $1.2 \mathrm{MgCl}_{2}$, and 5 Na-pyruvate; $\mathrm{pH} 7.4$ ) containing $20 \mathrm{mM}$ taurine, which replaced an equimolar amount of $\mathrm{NaCl}, 1.35 \mathrm{mg} / \mathrm{mL}$ collagenase (type XI), $1 \mathrm{mg} / \mathrm{mL}$ soybean trypsin inhibitor, and $1 \mathrm{mg} / \mathrm{mL}$ bovine serum albumin. This solution was gently bubbled with a $95 \% \mathrm{O}_{2}-5 \% \mathrm{CO}_{2}$ gas mixture to stir the enzyme solution and cells isolated as previously described [35]. Cells stored in $0.05 \mathrm{mM} \mathrm{Ca}^{2+}$ external solution containing $20 \mathrm{mM}$ taurine and $0.5 \mathrm{mg} / \mathrm{mL}$ bovine serum albumin at $4{ }^{\circ} \mathrm{C}$ under air were used for experiments within two days after isolation [36].

\subsubsection{Whole-Cell Patch Clamp Recordings}

The conventional whole-cell patch-clamp method was employed to voltage clamp smooth muscle cells. Recording electrodes were pulled from borosilicate glass capillaries (WPI, Berlin, Germany) and fire-polished to obtain a pipette resistance of 2-5 M $\Omega$ when filled with internal solution. An Axopatch 200B patch-clamp amplifier (Molecular Devices Corporation, Sunnyvale, CA, USA) was used to generate and apply voltage pulses to the clamped cells and record the corresponding membrane currents. At the beginning of each experiment, the junction potential between the pipette and bath solution was electronically adjusted to zero. Cells were continuously superfused using a peristaltic pump (LKB 2132, Bromma, Sweden) at a flow rate of $400 \mu \mathrm{L} / \mathrm{min}$. Current signals, after compensation for whole-cell capacitance and series resistance (between $70 \%$ and $75 \%$ ), were low-pass filtered at $1 \mathrm{kHz}$ and digitized at $3 \mathrm{kHz}$ prior to being stored on the computer hard disk. Electrophysiological responses were tested at room temperature $\left(20-22^{\circ} \mathrm{C}\right)$.

\subsection{4. $\mathrm{I}_{\mathrm{KCa} 1.1}$ Current Measurement}

$\mathrm{I}_{\mathrm{KCa} 1.1}$ (registration period $500 \mathrm{~ms}$ ) was measured over a range of test potentials from -20 to $70 \mathrm{mV}$ from a $\mathrm{V}_{\mathrm{h}}$ of $-40 \mathrm{mV}$. This $\mathrm{V}_{\mathrm{h}}$ limited the contribution of $\mathrm{K}_{\mathrm{V}}$ channels to the overall whole-cell current. Data were collected once the current amplitude had been stabilized (usually 8-10 min after the whole-cell configuration had been obtained). $\mathrm{I}_{\mathrm{KCa}} .1$ current did not run down during the following 20-30 min under the present experimental conditions [7]. The external solution for $\mathrm{I}_{\mathrm{KCa} .1}$ recordings contained (in $\mathrm{mM}$ ): $145 \mathrm{NaCl}, 6$ 
$\mathrm{KCl}, 10$ glucose, 10 HEPES, 5 Na-pyruvate, $1.2 \mathrm{MgCl}_{2}, 0.1 \mathrm{CaCl}_{2}, 0.003$ nicardipine (pH 7.4). The internal solution contained (in $\mathrm{mM}$ ): $90 \mathrm{KCl}, 10 \mathrm{NaCl}, 10$ HEPES, 10 EGTA, $1 \mathrm{MgCl}_{2}$, $6.41 \mathrm{CaCl}_{2}$ (pCa 7.0); pH 7.4. The osmolarity of the external (310 mosmol) and internal solutions (265 mosmol) were measured with an osmometer (Osmostat OM 6020, Menarini Diagnostics, Florence, Italy). The current-voltage relationships were calculated on the basis of the values recorded during the last $200 \mathrm{~ms}$ of each test pulse (leakage corrected). $\mathrm{I}_{\mathrm{KCa} .1}$ was isolated from other currents as well as corrected for leakage using $1 \mathrm{mM}$ TEA, a specific blocker of $\mathrm{K}_{\mathrm{Ca}} 1.1$ channels [7].

\subsection{5. $\mathrm{I}_{\mathrm{Ba1} .2}$ Recording}

Cells were continuously superfused with external solution containing $0.1 \mathrm{mM} \mathrm{Ca}^{2+}$ and $30 \mathrm{mM}$ tetraethylammonium (TEA). The internal solution (pCa 8.4) consisted of (in $\mathrm{mM}$ ): $100 \mathrm{CsCl}, 10$ HEPES, 11 EGTA, $2 \mathrm{MgCl}_{2}, 1 \mathrm{CaCl}_{2}, 5$ Na-pyruvate, 5 succinic acid, 5 oxaloacetic acid, $3 \mathrm{Na}_{2} \mathrm{ATP}$, and 5 phosphocreatine; the $\mathrm{pH}$ was adjusted to 7.4 with $\mathrm{CsOH} . \mathrm{I}_{\mathrm{Ba} 1.2}$, recorded in an external solution containing $30 \mathrm{mM}$ TEA and $5 \mathrm{mM} \mathrm{Ba}{ }^{2+}$, was elicited with $250 \mathrm{~ms}$ clamp pulses $(0.067 \mathrm{~Hz})$ to $0 \mathrm{mV}$ from a $\mathrm{V}_{\mathrm{h}}$ of $-50 \mathrm{mV}$. Data were collected once the current amplitude had been stabilized (usually 7-10 min after the whole-cell configuration had been obtained). Under these conditions, the current did not run down during the following $40 \mathrm{~min}$ [37]. $\mathrm{K}^{+}$currents were blocked with $30 \mathrm{mM}$ TEA in the external solution and $\mathrm{Cs}^{+}$in the internal solution. Current values were corrected for leakage and residual outward currents using $10 \mu \mathrm{M}$ nifedipine, which completely blocked $\mathrm{I}_{\mathrm{Ba} 1.2}$. The osmolarity of the $30 \mathrm{mM}$ TEA- and $5 \mathrm{mM} \mathrm{Ba}^{2+}$-containing external solution and that of the internal solution were $320 \mathrm{mOsmol}$ and $290 \mathrm{mOsmol}$, respectively.

\subsubsection{Drugs and Chemicals}

The chemicals used included: collagenase (type XI), trypsin inhibitor, bovine serum albumin, TEA chloride, taurine, nicardipine, and nifedipine (Merck, Milan, Italy). All other substances were of analytical grade and used without further purification. Nifedipine and nicardipine, dissolved directly in ethanol, and compound 1, dissolved directly in DMSO, were diluted at least 1000 times prior to use. Control experiments confirmed that no response was induced in vascular preparations when DMSO or ethanol, at the final concentration used in the above dilutions $(0.1 \%, v / v)$, was added alone (data not shown). Final drug concentrations are stated in the text.

\subsubsection{Statistical Analysis}

Analysis of data was accomplished by using pClamp 9.2.1.8 software (Molecular Devices Corporation, San Jose, CA, USA) and GraphPad Prism version 5.04 (GraphPad Software Inc., San Diego, CA, USA). Data are reported as mean \pm s.e.m.; $n$ is the number of cells analyzed (indicated in parentheses), isolated from at least three animals. Statistical analysis and significance, as measured by repeated measures ANOVA (followed by Dunnett's post hoc test), or Student's $t$ test for paired samples (two tailed) were obtained using GraphPad Prism version 5.04 (GraphPad Software Inc., San Diego, CA, USA). In all comparisons, $p<0.05$ was considered significant.

\section{Conclusions}

In this short note, the design and synthesis of the $3^{\prime}$-ferulic ester derivative of quercetin were reported along with the assessment of its effects on vascular $\mathrm{K}_{\mathrm{Ca}} 1.1$ and $\mathrm{Ca}_{\mathrm{V}} 1.2$ channels. A simple and time-saving synthetic protocol, characterized by the direct acylation of quercetin under mild and strongly controlled reaction conditions followed by careful chromatographic purification with gradient elution, was developed. In silico analysis pointed out the ability of the new hybrid compound to bind with high affinity on the $\mathrm{K}_{\mathrm{Ca}} 1.1$ channel, justifying a possible vascular ion channel modulatory activity. Pharmacological findings suggest that the introduction of a $3^{\prime}$-ferulic ester moiety in quercetin structure caused a partial reduction of its stimulatory activity on both $\mathrm{K}_{\mathrm{Ca}} 1.1$ and $\mathrm{Ca}_{\mathrm{V}} 1.2$ channels. 
It is conceivable, therefore, that its vasorelaxant activity is not improved, though only functional experiments performed on isolated vessels may clarify this point. In the light of the results presented here, it cannot be ruled out that reduction of both activities may be due either to the presence of the ferulic acid or to the loss of the quercetin $3^{\prime}-\mathrm{OH}$ group, or both. It is well known, in fact, that the number and/or position of $\mathrm{OH}$ groups in the flavonoid scaffold are crucial determinants of their pharmacological activity. The design strategy aimed to improve quercetin beneficial vascular activity, therefore, this needs to be re-designed either positioning ferulic acid in a different position or replacing it with different substituents, as recently shown for the same flavonoid [4] or its analogue morin [5].

Supplementary Materials: ${ }^{1} \mathrm{H}$ - and ${ }^{13} \mathrm{C}-\mathrm{NMR}$ spectra, $\mathrm{HSQC}$ and $\mathrm{HMBC}$ experiments are available online, Figures S1-S2: ${ }^{1} \mathrm{H}$ - and ${ }^{13} \mathrm{C}$-NMR spectra of quercetin, Figures S3-S4: ${ }^{1} \mathrm{H}$ - and ${ }^{13} \mathrm{C}-\mathrm{NMR}$ spectra of ferulic acid, Figures S5-S8: ${ }^{1} \mathrm{H}$ - and ${ }^{13} \mathrm{C}-\mathrm{NMR}$ spectra of compound 1, Figures S9-S10: HSQC spectra of compound 1, Figures S11-S12: HMBC spectra of compound 1, Figure S13: Table S1 reporting $\mathrm{K}_{\mathrm{Ca}} 1.1$ channel-compound interaction network.

Author Contributions: Conceptualization, A.B., S.S. and F.F.; methodology, A.T., O.S., F.S., S.S. and F.F.; software, A.T., S.S. and F.F.; validation, A.T., S.S. and F.F.; synthesis and formal analysis, A.B., S.M. and F.S.; NMR experiments S.M.; investigation, A.B.; data curation, A.T., F.S., S.S. and F.F.; writingoriginal draft preparation, A.B. and S.S.; writing-review and editing, A.B. and S.S.; supervision, F.F.; funding acquisition, A.B. and F.F. All authors have read and agreed to the published version of the manuscript.

Funding: This research was partially funded by MIUR Progetto Dipartimenti di Eccellenza 2018-2022, grant n. L. 232/2016.

Institutional Review Board Statement: All experimental protocols were approved by the Animal Care and Ethics Com-mittee of the University of Siena and Italian Department of Health (7DF19.N.TBT) and carried out in accordance with the European Union Guidelines for the Care and the Use of Laboratory Animals (European Union Directive 2010/63/EU)" was reported in Method Section, Section 3.3.1.

Informed Consent Statement: Not applicable.

Data Availability Statement: Not applicable.

Acknowledgments: Authors from Department of Biotechnology, Chemistry and Pharmacy acknowledge the partial support by MIUR Progetto Dipartimenti di Eccellenza 2018-2022, grant n. L. 232/2016 and M. Taddei for granting the use of the $600 \mathrm{MHz}-\mathrm{NMR}$ instrument.

Conflicts of Interest: The authors declare no conflict of interest.

\section{References}

1. Patel, R.V.; Mistry, B.M.; Shinde, S.K.; Syed, R.; Singh, V.; Shin, H.-S. Therapeutic potential of quercetin as a cardiovascular agent. Eur. J. Med. Chem. 2018, 155, 889-904. [CrossRef]

2. Scholz, E.P.; Zitron, E.; Katus, H.A.; Karle, C.A. Cardiovascular ion channels as a molecular target of flavonoids. Cardiovasc. Ther. 2010, 28, 46-52. [CrossRef]

3. Saponara, S.; Carosati, E.; Mugnai, P.; Sgaragli, G.; Fusi, F. The flavonoid scaffold as a template for the design of modulators of the vascular Ca(v) 1.2 channels. Br. J. Pharmacol. 2011, 164, 1684-1697. [CrossRef]

4. Fusi, F.; Spiga, O.; Trezza, A.; Sgaragli, G.; Saponara, S. The surge of flavonoids as novel, fine regulators of cardiovascular Cav channels. Eur. J. Pharmacol. 2017, 796, 158-174. [CrossRef]

5. Fusi, F.; Trezza, A.; Tramaglino, M.; Sgaragli, G.; Saponara, S.; Spiga, O. The beneficial health effects of flavonoids on the cardiovascular system: Focus on K+ channels. Pharmacol. Res. 2020, 152, 104625. [CrossRef]

6. Saponara, S.; Sgaragli, G.; Fusi, F. Quercetin as a novel activator of L-type $\mathrm{Ca}(2+)$ channels in rat tail artery smooth muscle cells. Br. J. Pharmacol. 2002, 135, 1819-1827. [CrossRef]

7. Iozzi, D.; Schubert, R.; Kalenchuk, V.U.; Neri, A.; Sgaragli, G.; Fusi, F.; Saponara, S. Quercetin relaxes rat tail main artery partly via a PKG-mediated stimulation of KCa 1.1 channels. Acta Physiol. (Oxf.) 2013, 208, 329-339. [CrossRef] [PubMed]

8. Sonkusare, S.; Palade, P.T.; Marsh, J.D.; Telemaque, S.; Pesic, A.; Rusch, N.J. Vascular calcium channels and high blood pressure: Pathophysiology and therapeutic implications. Vasc. Pharmacol. 2006, 44, 131-142. [CrossRef] 
9. Cox, R.H.; Rusch, N.J. New expression profiles of voltage-gated ion channels in arteries exposed to high blood pressure. Microcirculation 2002, 9, 243-257. [CrossRef]

10. Magar, R.T.; Sohng, J.K. A review on structure, modifications and structure-activity relation of quercetin and its derivatives. $J$. Microbiol. Biotechnol. 2020, 30, 11-20. [CrossRef]

11. Badolato, M.; Carullo, G.; Perri, M.; Cione, E.; Manetti, F.; Di Gioia, M.L.; Brizzi, A.; Caroleo, M.C.; Aiello, F. Quercetin/oleic acid-based G-protein-coupled receptor 40 ligands as new insulin secretion modulators. Future Med. Chem. 2017, 9, 1873-1885. [CrossRef]

12. Carullo, G.; Ahmed, A.; Trezza, A.; Spiga, O.; Brizzi, A.; Saponara, S.; Fusi, F.; Aiello, F. Design, synthesis and pharmacological evaluation of ester-based quercetin derivatives as selective vascular $\mathrm{K}_{\mathrm{Ca}} 1.1$ channel stimulators. Bioorg. Chem. 2020, 105, 104404. [CrossRef]

13. Carullo, G.; Ahmed, A.; Trezza, A.; Spiga, O.; Brizzi, A.; Saponara, S.; Fusi, F.; Aiello, F. A multitarget semi-synthetic derivative of the flavonoid morin with improved in vitro vasorelaxant activity: Role of CaV1.2 and KCa1.1 channels. Biochem. Pharmacol. 2021, 185, 114429. [CrossRef] [PubMed]

14. Mazzotta, S.; Governa, P.; Borgonetti, V.; Marcolongo, P.; Nanni, C.; Gamberucci, A.; Manetti, F.; Pessina, F.; Carullo, G.; Brizzi, A.; et al. Pinocembrin and its linolenoyl ester derivative induce wound healing activity in HaCaT cell line potentially involving a GPR120/FFA4 mediated pathway. Bioorg. Chem. 2021, 108, 104657. [CrossRef]

15. Chaudhary, A.; Jaswal, V.S.; Choudhary, S.; Sonika; Sharma, A.; Beniwal, V.; Tuli, H.S.; Sharma, S. Ferulic acid: A promising therapeutic phytochemical and recent patents advances. Recent Pat. Inflamm. Allergy Drug Discov. 2019, 13, 115-123. [CrossRef]

16. Fuentes, E.; Palomo, I. Mechanisms of endothelial cell protection by hydroxycinnamic acids. Vasc. Pharmacol. 2014, 63, 155-161. [CrossRef]

17. Niu, X.; Qian, X.; Magleby, K.L. Linker-gating ring complex as passive spring and $\mathrm{Ca}(2+)$-dependent machine for a voltage- and $\mathrm{Ca}(2+)$-activated potassium channel. Neuron 2004, 42, 745-756. [CrossRef]

18. Gessner, G.; Cui, Y.M.; Otani, Y.; Ohwada, T.; Soom, M.; Hoshi, T.; Heinemann, S.H. Molecular mechanism of pharmacological activation of BK channels. Proc. Natl. Acad. Sci. USA 2012, 109, 3552-3557. [CrossRef]

19. Bouktaib, M.; Lebrun, S.; Atmani, A.; Rolando, C. Hemisynthesis of all the $O$-monomethylated analogues of quercetin including the major metabolites, through selective protection of phenolic functions. Tetrahedron 2002, 58, 10001-10009. [CrossRef]

20. Trouillas, P.; Marsal, P.; Siri, D.; Lazzaroni, R.; Duroux, J.-L. A DFT study of the reactivity of OH groups in quercetin and taxifolin antioxidants: The specificity of the 3-OH site. Food Chem. 2006, 97, 679-688. [CrossRef]

21. Veverka, M.; Gallovič, J.; Švajdlenka, E.; Ververková, E.; Prónayová, N.; Miláčková, I.; Štefek, M. Novel quercetin derivatives: Synthesis and screening for anti-oxidant activity and aldose reductase inhibition. Chem. Pap. 2013, 67, 76-83. [CrossRef]

22. Salem, J.H.; Humeau, C.; Chevalot, I.; Harscoat-Schiavo, C.; Vanderesse, R.; Blanchard, F.; Fick, M. Effect of acyl donor chain length on isoquercitrin acylation and biological activities of corresponding esters. Process Biochem. 2010, 45, 382-389. [CrossRef]

23. Saik, A.Y.H.; Lim, Y.Y.; Stanslas, J.; Choo, W.M. Enzymatic synthesis of quercetin oleate esters using Candida antarctica lipase B. Biotechnol. Lett. 2017, 39, 297-304. [CrossRef]

24. Soltesova-Prnova, M.; Milackova, I.; Stefek, M. 3'-O-(3-Chloropivaloyl)quercetin, $\alpha$-glucosidase inhibitor with multi-targeted therapeutic potential in relation to diabetic complications. Chem. Pap. 2016, 70, 1439-1444. [CrossRef]

25. Kumar, V.; Jahan, F.; Mahajan, R.V.; Kumar Saxena, R. Efficient regioselective acylation of quercetin using Rhizopus oryzae lipase and its potential as antioxidant. Bioresour. Technol. 2016, 218, 1246-1248. [CrossRef] [PubMed]

26. Russo, N.; Toscano, M.; Uccella, N. Semiempirical Molecular Modeling into Quercetin Reactive Site: Structural, Conformational, and Electronic Features. J. Agric. Food Chem. 2000, 48, 3232-3237. [CrossRef]

27. Chebil, L.; Anthoni, J.; Humeau, C.; Gerardin, C.; Engasser, J.-M.; Ghoul, M. Enzymatic Acylation of Flavonoids: Effect of the Nature of the Substrate, Origin of Lipase, and Operating Conditions on Conversion Yield and Regioselectivity. J. Agric. Food Chem. 2007, 55, 9496-9502. [CrossRef] [PubMed]

28. Saik, A.Y.H.; Lim, Y.Y.; Stanslas, J.; Choo, W.S. Lipase-catalyzed acylation of quercetin with cinnamic acid. Biocatal. Biotransform. 2016, 34, 33-43. [CrossRef]

29. Kyriakou, E.; Primikyri, A.; Charisiadis, P.; Katsoura, M.; Gerothanassis, I.P.; Stamatis, H.; Tzakos, A.G. Unexpected enzymecatalyzed regioselective acylation of flavonoid aglycones and rapid product screening. Org. Biomol. Chem. 2012, 10, 1739. [CrossRef] [PubMed]

30. Moustakas, D.T.; Lang, P.T.; Pegg, S.; Pettersen, E.; Kuntz, I.D.; Brooijmans, N.; Rizzo, R.C. Development and validation of a modular, extensible docking program: DOCK 5. J. Comput. Aided Mol. Des. 2006, 20, 601-619. [CrossRef]

31. Koebel, M.R.; Schmadeke, G.; Posner, R.G.; Sirimulla, S. AutoDock VinaXB: Implementation of XBSF, new empirical halogen bond scoring function, into AutoDock Vina. J. Cheminform. 2016, 8, 27. [CrossRef] [PubMed]

32. O’Boyle, N.M.; Banck, M.; James, C.A.; Morley, C.; Vandermeersch, T.; Hutchison, G.R. Open babel: An open chemical toolbox. J. Cheminform. 2011, 3, 33. [CrossRef] [PubMed]

33. Morris, G.M.; Ruth, H.; Lindstrom, W.; Sanner, M.F.; Belew, R.K.; Goodsell, D.S.; Olson, A.J. Software news and updates AutoDock4 and AutoDockTools4: Automated docking with selective receptor flexibility. J. Comput. Chem. 2009, 30, $2785-2791$. [CrossRef] [PubMed]

34. Salentin, S.; Schreiber, S.; Haupt, V.J.; Adasme, M.F.; Schroeder, M. PLIP: Fully automated protein-ligand interaction profiler. Nucleic Acids Res. 2015, 43, W443-W447. [CrossRef] 
35. Fusi, F.; Saponara, S.; Sgaragli, G.; Cargnelli, G.; Bova, S. Ca(2+) entry blocking and contractility promoting actions of norbormide in single rat caudal artery myocytes. Br. J. Pharmacol. 2002, 137, 323-328. [CrossRef]

36. Mugnai, P.; Durante, M.; Sgaragli, G.; Saponara, S.; Paliuri, G.; Bova, S.; Fusi, F. L-type Ca(2+) channel current characteristics are preserved in rat tail artery myocytes after one-day storage. Acta Physiol. (Oxf.) 2014, 211, 334-345. [CrossRef]

37. Fusi, F.; Sgaragli, G.; Saponara, S. Mechanism of myricetin stimulation of vascular L-type Ca ${ }^{2+}$ current. J. Pharmacol. Exp. Ther. 2005, 313, 790-797. [CrossRef] 